\title{
TETRATHECA GUNNII HOOK. F. ON SERPENTINE SOILS NEAR BEACONSFIELD, TASMANIA
}

\author{
by M.J. Brown, H.J. Bayly-Stark, F. Duncan and N. Gibson
}

(with one table and two text-figures)

BROWN, M.J., BAYLY-STARK, H.J., DUNCAN, F.\& GIBSON, N., 1986 (12:ix): Tetratheca gunnii

Hook. f. on serpentine soils near Beaconsfield, Tasmania. Pap. Proc. R. Soc. Tasm. 120: 33-38. https://doi.org/10.26749/rstpp.120.33 ISSN 0080-4703. National Parks and Wildlife Service,

Sandy Bay, Tasmania 7005.

The rediscovery of Tetratheca gunnii Hook. f., a species last collected in 1843 and presumed extinct, is reported. The morphological variability among plants (including previously undescribed fruit) is given to facilitate comparison with descriptions of the type material. The habitat of the species is described and options for management to conserve viable populations are discussed.

Key Words: Tetratheca gunnii, serpentine, Tasmania, conservation.

\section{INTRODUCTION}

This paper reports the rediscovery of Tetratheca gunnii Hook. f., a species previously known only from the type and one duplicate collection made by R. C. Gunn in 1843 (Hooker 1855, in Thompson 1976). In their census of extinct and endangered Australian plants, Leigh et al. (1984) categorised T. gunnii as "presumed extinct". Leigh et al. (loc. cit.) and Thompson (loc. cit.) have emphasized the need to relocate the species, so that its specific status can be verified and appropriate conservation measures can be undertaken.

\section{THE STUDY AREA}

The holotype of $T$. gunnii was collected from the foothills of the Asbestos Range on serpentine rocks. The Asbestos Range and associated Dazzler Range form a dissected upland between the Tamar River (Port Dalrymple) and Port Sorell, reaching an altitude of $520 \mathrm{~m}$. The ranges are located in the moist subhumid and humid warm climatic zones respectively (Gentilli 1972). The area is geologically and topographically complex (Gee \& Legge 1971) and supports a range of vegetation types from rainforest through eucalypt forest to heath (Brown \& Buckney 1983, Kirkpatrick \& Dickinson 1984).

The search for Tetratheca gunnii was concentrated on the Cambrian serpentinite, peridotite and associated ultramafic rocks which crop out locally in undula ting terrain in the eastern foothills of the Dazzler Range, about $3 \mathrm{~km}$ west of Beaconsfield (fig. 1). The range of altitudes of these rocks is 20 to $220 \mathrm{~m}$. The vegetation mainly comprises dry

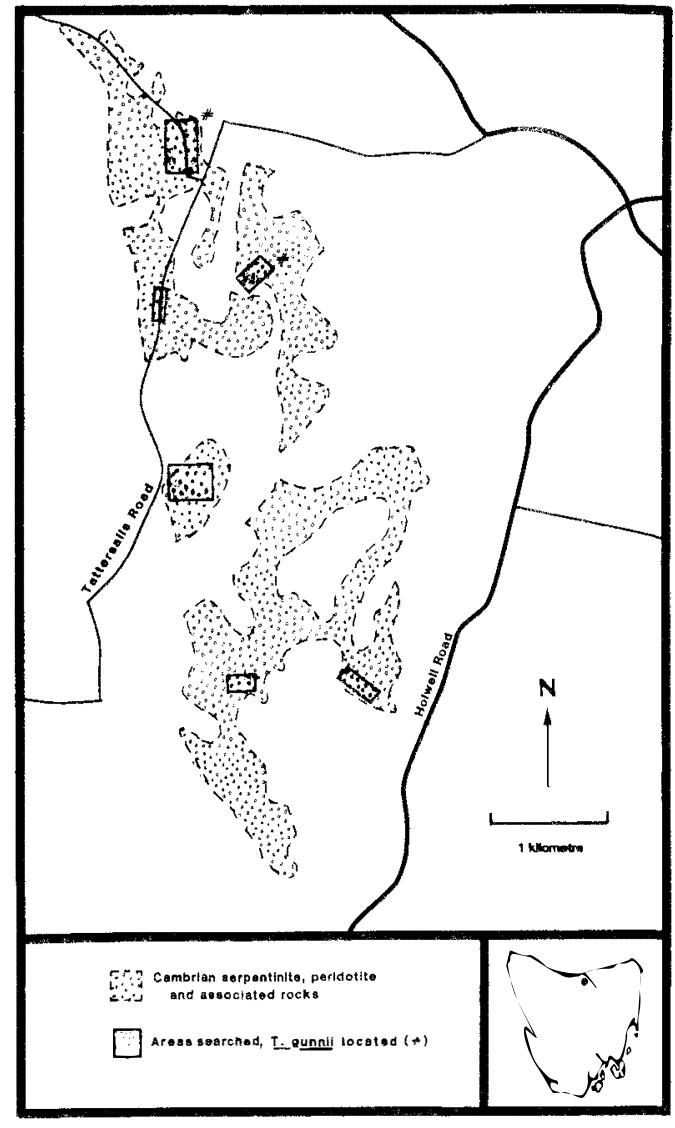

FIG.I - Map showing distribution of serpentine soils, areas searched and locations of $\mathrm{T}$. gunnii. 


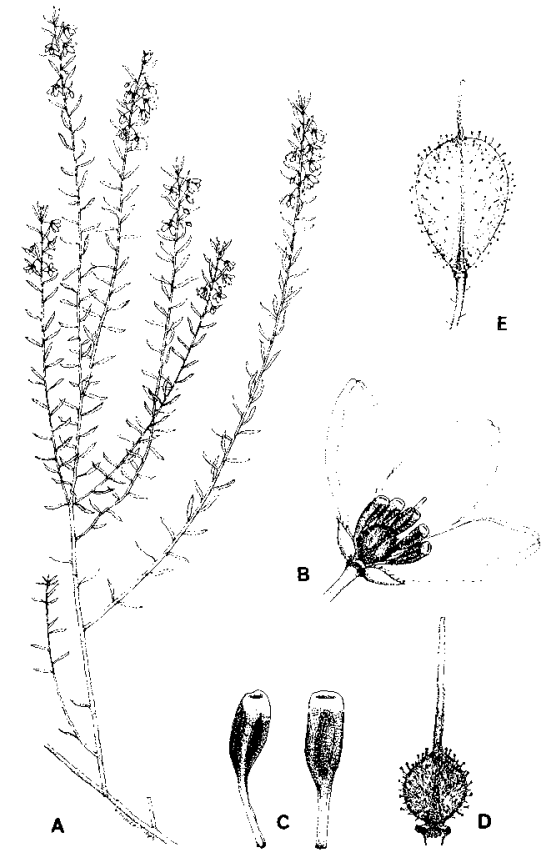

FIG.2 - Tetratheca gunnii: (a) habit of flowering specimen, $x 0.75$; (b) flower with one sepal, one petal and three siamens removed, $x 7.5 ;$ (c) stamens, x15; (d) ovary and style, xI5; (e) fruit, x7.5.

sclerophyll forest with a heathy or shrubby understorey. Shafts, scrapes and spoil heaps are common in the serpentinite area, which was worked previously for asbestos and more recently for chromite. Other land uses in the immedia te area are logging for pulp, sawlogs and firewood, grazing, clearing, gravel extraction and protection of water quality (water reserve).

The area was searched by the authors on 3 October 1985 when the initial findings were made. The area was revisited on 19 December 1985 to obtain fruiting material for description and seed for propagation by the Royal Tasmanian Botanical Gardens. Specimens are lodged with the Tasmanian Herbarium ( $\mathrm{HO}$ ).

\section{RESULTS AND DISCUSSION}

\section{Occurrence and Habitat}

Plants were found growing on shallow soils at four distinct locations in two of the six areas searched (fig. 1). All of the sites were underlain by serpentine rocks (Gee \& Legge 1971). A total of 24 individuals were found with 20 in one population, two in another and the remaining two plants occurring as solitary individuals. In each case, the plants were found growing on gently sloping hillsides of east to southeast aspect in heathy Eucalyptus amygdalina woodland (Duncan \& Brown 1985). Eucalyptus amygdalina is the overstorey dominant, with E. ovata present as a minor species. Casuarina littoralis and Banksia marginata form a small tree-tall shrub stratum over a dense hea th dominated by Epacris virgata, Correa reflexa and Hibbertia riparia. Cutting grass (Gahnia spp.), grasses, saggs and procumbent shrubs are also widespread. Species lists for each site are given in appendix 1 .

At each location, T. gunnii is closely associated with two other endemic species, also largely restricted to serpentine rocks, viz. Epacris virgata and Spyridium obcordatum (Kirkpatrick \& Brown 1984). However, the latter two species are much more abundant. Serpentine rocks worldwide are noted for their high local endemicity (e.g. Whittaker 1954, Kruckeberg 1954) and those near Beaconsfield appear to be no exception.

Kruckeberg (1954) presented evidence that serpentine endemics are unable to compete with non-serpentine species in comparatively dense closed communities. The very pronounced boundaries of the Epacris virgata population indicate that this species is a serpentine endemic. Spyridium obcordatum is strongly associated with serpentine rocks, but does occur albeit rarely, on other rock types (Brown et al. 1983) and may represent an example of biotype depletion (Stebbins 1942). Tetratheca gunnii has only been found on serpentine rocks and may be a serpentine endemic. It exhibits "serpentomorphic" characteristics (Whittaker 1954) as compared with its close congener $T$. pilosa. The latter species occurs with $T$. gunnii on this rock type but is found more widely in other edaphic situations. The ecological and genecological status of $T$. gunnii can only be confirmed by further investigations.

\section{Description}

In most respects, the plants found in the present study fit closely to the description of $T$. gunnii given by Thompson (1976). The absence of an anther tube is particularly distinctive (fig. 2) and immediately separates the species from $T$. pilosa and from the morphologically similar $T$. procumbens Gunn ex Hook. f. (which is included in $T$. pilosa by Thompson loc. cit.). 


\section{TABLE 1}

Morphometric Data for Tetratheca gunnii. Mean Value (and ranges) in $\mathrm{mm}$.

\begin{tabular}{|c|c|c|c|c|c|c|c|}
\hline & \multirow[t]{2}{*}{ Site } & \multirow[t]{2}{*}{ Site 2} & \multicolumn{2}{|c|}{ Sites 3 and 4} & \multirow[b]{2}{*}{$\mathbf{P 3}$} & \multirow[b]{2}{*}{ P4 } & \multirow[b]{2}{*}{ Mean } \\
\hline & & & $\mathbf{P 1}$ & $\mathbf{P 2}$ & & & \\
\hline $\begin{array}{l}\text { Leaf length } \\
\text { (blade) }\end{array}$ & $\begin{array}{c}5.4 \\
(5.2-5.8)\end{array}$ & $\begin{array}{c}3.5 \\
(3.0-3.8)\end{array}$ & $\begin{array}{c}5.1 \\
(4.2-5.8)\end{array}$ & $\begin{array}{c}4.1 \\
(3.8-4.5)\end{array}$ & $\begin{array}{c}5.2 \\
(4.8-5.8)\end{array}$ & $\begin{array}{c}4.6 \\
(3.6-5.5)\end{array}$ & 4.65 \\
\hline $\begin{array}{l}\text { Leaf width } \\
\qquad \max )\end{array}$ & $\begin{array}{c}1.0 \\
(0.9-1.0)\end{array}$ & $\begin{array}{c}0.9 \\
(0.7-1.2)\end{array}$ & $\begin{array}{c}1.1 \\
(0.9-1.2)\end{array}$ & $\begin{array}{c}1.1 \\
(0.9-1.4)\end{array}$ & $\begin{array}{c}1.0 \\
(0.9-1.1)\end{array}$ & $\begin{array}{c}0.9 \\
(0.6-1.1)\end{array}$ & 1.0 \\
\hline Petal length & $\begin{array}{c}3.4 \\
(3.0-4.2)\end{array}$ & $\begin{array}{c}2.6 \\
(2.2-3.2)\end{array}$ & $\begin{array}{c}5.2 \\
(4.6-5.7)\end{array}$ & $\begin{array}{c}4.5 \\
(4.0-5.2)\end{array}$ & $\begin{array}{c}4.5 \\
(4.0-4.8)\end{array}$ & $\begin{array}{c}3.5 \\
(3.3-3.9)\end{array}$ & 4.0 \\
\hline Sepal length & $\begin{array}{c}1.0 \\
(1.0-1.0)\end{array}$ & $\begin{array}{c}0.9 \\
(0.9-1.0)\end{array}$ & $\begin{array}{c}1.3 \\
(1.2-1.3)\end{array}$ & $\begin{array}{c}1.0 \\
(1,0-1.1)\end{array}$ & $\begin{array}{c}1.0 \\
(1.0)\end{array}$ & $\begin{array}{c}1.1 \\
(1.0-1.1)\end{array}$ & 1.05 \\
\hline Stamen length & $\begin{array}{c}2.1 \\
(2.0-2.2)\end{array}$ & $\begin{array}{c}1.4 \\
(1.2-1.6)\end{array}$ & $\begin{array}{c}2.6 \\
(2.5-2.7)\end{array}$ & $\begin{array}{c}2.4 \\
(2.3-2.4)\end{array}$ & $\begin{array}{c}2.3 \\
(2.1-2.4)\end{array}$ & $\begin{array}{c}1.9 \\
(1.8-2.2)\end{array}$ & 2.1 \\
\hline Peduncle length & $\begin{array}{c}3.6 \\
(3.2-4.3)\end{array}$ & $\begin{array}{c}2.4 \\
(2.1-2.6)\end{array}$ & $\begin{array}{l}2.3 \\
(1.5-2.7)\end{array}$ & $\begin{array}{c}2.4 \\
(1.9-2.7)\end{array}$ & $\begin{array}{c}2.7 \\
(2.4-3.1)\end{array}$ & $\begin{array}{c}2.3 \\
(2.3)\end{array}$ & 2.6 \\
\hline Style length & $\begin{array}{c}1.6 \\
(1.4-1.8)\end{array}$ & $\begin{array}{c}1.3 \\
(1.2-1.5)\end{array}$ & $\begin{array}{c}2.1 \\
(2.0-2.1)\end{array}$ & $\begin{array}{c}1.9 \\
(1.8-2.0)\end{array}$ & $\begin{array}{c}2.0 \\
(2.0)\end{array}$ & $\begin{array}{c}2.0 \\
(1.9-2.0)\end{array}$ & 1.8 \\
\hline $\begin{array}{l}\text { Stem width } \\
\text { (internodal in } \\
\text { flowering section) }\end{array}$ & $\begin{array}{c}0.6 \\
(0.6)\end{array}$ & $\begin{array}{c}0.7 \\
(0.7)\end{array}$ & $\begin{array}{c}0.7 \\
(0.7)\end{array}$ & $\begin{array}{c}0.6 \\
(0.6)\end{array}$ & $\begin{array}{c}0.7 \\
(0.7)\end{array}$ & $\begin{array}{c}0.7 \\
(0.7)\end{array}$ & 0.7 \\
\hline
\end{tabular}

Plants are generally lax and less than $0.3 \mathrm{~m}$ tall, but one individual was erect to $0.8 \mathrm{~m}$. The plants are smaller in all their parts than $T$. pilosa especially in comparison with the robust forms of the latter which grow in the same area. Table 1 gives some morphometric data from six plants of T. gunnii to indicate variability between plants.

The petals vary in colour from pale lilac to deep pink-purple. Thompson (loc. cit.) suggests that the petals are usually white, but no white flowered specimens were seen. However, flowers on some specimens did fade within a few days of collection.

The fruit is a compressed 2(-3) locular capsule, obovate to cuneate, turgid $4.0 \mathrm{~mm}$ long, 2.5-3.0 $\mathrm{mm}$ wide, with uniform cover of sparsely scattered gland-tipped hairs. Slightly channelled along septum, style not persistent, opening along margin.

Seeds are pale, $3.0 \mathrm{~mm}$ long, almost oblong, covered with fine, appressed to spreading hairs, a ppendage pale covered with finer hairs. Similar to $T$. pilosa but base not scarred.

\section{Conservation and Management}

It seems likely that the serpentine provides the only suitable habitat for $T$. gunnii, and its distribution is very restricted even on this geological type. The serpentine rocks in the area occupy 530 ha, of which 270 ha $(51 \%)$ is State Forest, 220 ha $(41 \%)$ is privately owned and 40 ha $(8 \%)$ is Crown Water Reserve. All of the T. gunnii plants found were in State Forest.

The main risks to survival for the species appear to be land clearing, adverse firing and grazing regimes and overcollecting. Some of the private land in the area has been cleared to rough pasture, to the detriment of Epacris virgata and Spyridium obcordaium, and further clearing for agriculture and for gravel extraction are potential threats. There is good evidence that grazing by introduced stock and frequent firing on State Forest in the area were also detrimental to the above species in the past. There has been a dramatic increase in the abundance and vigour of $E$. virgata on some previously grazed sites following recent cessation of grazing. Duncan (1981) has shown that Tetratheca glandulosa $(=$ T. labillardieri Thompson) is dependent on seed for regeneration following a hot fire. If the same applies to $T$. gunnii, then fire regimes suitable for the maintenance of the populations will have to be determined.

The serpentine a reas on State Forest generally support poor stands of timber, and are unlikely to 
be clearfelled. Clearing of tracks for timber, mining or gravel extraction may not pose a direct threat to the species. However there remains the problem of possible introduced pathogens. The effects of Phytophthora cinnamomi on serpentine soils in general and T. gunnii in particular are unknown. Other species of Tetratheca are very susceptible to attack, but no symptoms consistent with $P$. cinnamomi infection were evident in the a rea. Soils in the area have been tested previously, but no $P$. cinnamomi was recovered.

The occurrence of $T$. gunnii in such close association with other restricted endemic species, confers on the area a very high significance for biological conservation. It is essential that a monitoring programme be established to continually review the status of $T$. gunnii, which has now been confirmed as an extant but endangered species.

\section{ACKNOWLEDGEMENTS}

We wish to thank S.J. Jarman, A.E. Orchard and N.J. Turner for their comments on the draft manuscript. The survey was undertaken during projects funded by the Australian Heritage Commission (FD), the Australian National Parks and Wildlife Service and the Tasmanian Forestry Commission (NG).

\section{REFERENCES}

BROWN, M.J. \& BUCKNEY, R.T., 1983: Structural and floristic variation in the forest communities of the West Tamar, Tasmania. Pap. Proc. R. Soc. Tasm. 117: 135-147.

BROWN, M.J., KIRKPATRICK, J.B. \& MOSCAL, A., 1983: AN ATLAS OF TASMANIA'S ENDEMIC FLORA. Tasmanian Conservation Trust, Hobart.

CURTIS, W.M., 1963: THE STUDENT'S FLORA OF TASMANIA PART 2. Government Printer, Tasmania.

CURTIS, W.M., 1967: THE STUDENT'S FLORA OF TASMANIA PART 3. Government Printer, Tasmania.

CURTIS, W.M. \& MORRIS, D.1., 1975: THE STUDENT'S FLORA OF TASMANIA PARTI (2NDED.). Government Printer, Tasmania.

DUNCAN, F., 1981: Regeneration and species diversity in a Tasmanian dry sclerophyll forest. In KIRKPATRICK, J.B. (Ed.): FIRE AND FOREST MANAGEMENT IN TASMANIA. Tasmanian Conservation Trust, Hobart: 33-44.

DUNCAN, F. \& BROWN, M.J., 1985: Dry sclerophyll vegetation in Tasmania. Extent and conservation status of the communities. Wildl. Divn Tech. Rept 85/1. National Parks and Wildlife Service, Tasmania.

GEE, R.D. \& LEGGE, P.J., 1971: BEACONSFIELD: TASMANIA DEPT OF MINES GEOLOGICALATLAS 1:63,360 SERIES. Department of Mines, Hobart.

GENTILLI, J., 1972: AUSTRALIAN CLIMATIC PATTERNS. Nelson, Melbourne.

KIRKPATRICK, J.B. \& BROWN, M.J., 1984: A numerical analysis of Tasmanian higher plant endemism. Bot. J. Linn. Soc. (London) 88: $165-183$.

KIRKPATRICK, J.B. \& DICKINSON, K.J.M., 1984: VEGETATION OF TASMANIA, 1:500,000 MAP. Forestry Commission, Tasmania.

KRUCKEBERG, A.R., 1954: The ecology of serpentine soils. III. Plant species in relation to serpentine soils. Ecology 35: 267-274.

LEIGH, J., BODEN, R. \& BRIGGS, J., 1984: EXTINCT AND ENDANGERED PLANTS OF AUSTRALIA. Macmillan, Melbourne.

STEBBINS, G.L., 1942: The genetic approach to problems of rare and endemic species. Madrono 6 : 241-272.

THOMPSON, J., 1976: A revision of the Genus Terratheca (Tremandraceae). Telopea 1: 139-215.

WHITTAKER, R.H., 1954: The ecology of serpentine soils. IV. The vegetational response to serpentine soils. Ecology 35: 275-288.

WILLIS, J.H., 1970: A HANDBOOK OF PLANTS IN VICTORIA. Vol.I Ferns, Conifers and Monocotyledons. Melbourne University Press.

(accepted Nov. 27, 1985) 


\section{APPENDIX 1}

List of Vascular Species Associated with Tetratheca gunnii Hook. F. Near Beaconsfield.

A comprehensive list of species is given below for each $T$. gunnii site. Species were recorded from a circular plot of a nominal $15 \mathrm{~m}$ radius, which was centred on each population of $T$. gunnit. Except where indicated, species authorities are those given by Brown et al. (1983) for endemics, Curtis $(1963,1967)$ and Curtis and Morris (1975) for other dicotyledons, and Willis (1970) for other monocotyledons and pteridophytes. Endemic species are prefixed by an 'e', introduced species by an 'i', and poorly reserved species (Brownet al. 1983) by an 's'. Abundance of each species on each site is indicated by: $+=$ uncommon; $0=$ occasional; $a=$ abundant and/or dense. The numbers of $T$. gunnii recorded from each site a re: site I one plant; site $2-$ one plant, site 3 - two plants, site 4 - twenty plants.

\begin{tabular}{|c|c|c|c|c|c|c|}
\hline & & & \multicolumn{4}{|c|}{ SITE } \\
\hline & & & 1 & 2 & 3 & 4 \\
\hline \multicolumn{7}{|l|}{ PTERIDOPHYTES } \\
\hline Aspleniaceae & & Asplenium flabellifolium & + & & & \\
\hline Dennstaedtiaceae & & Pteridium esculentum & + & 0 & + & 0 \\
\hline Lindsaeaceae & & Lindsaea linearis & + & & & + \\
\hline Sinopteridaceae & & Cheilanihes tenuifolia & + & & & \\
\hline \multicolumn{7}{|l|}{ DICOTYLEDONS } \\
\hline \multirow[t]{8}{*}{ Asteraceae } & & Craspedia glauca & + & & & \\
\hline & & Gnaphalium sp. & + & & & \\
\hline & & Helichrysum dendroideum & + & + & & \\
\hline & & Helichrysum scorpioides & + & + & + & + \\
\hline & $\mathrm{i}$ & Hypochaeris radicata & & + & & \\
\hline & & Olearia erubescens & & & + & \\
\hline & & Olearia liraia & + & & & \\
\hline & & Olearia ramulosa & & + & & \\
\hline Campanulaceae & & Wahlenbergia sp. & + & & & + \\
\hline Casuarinaceac & & Casuarina littoralis & a & $\mathrm{a}$ & a & a \\
\hline Dilleniaceae & & Hibbertia riparia & a & $\mathrm{a}$ & $\mathrm{a}$ & a \\
\hline Droseraceae & & Drosera auriculala & + & & + & \\
\hline \multirow[t]{5}{*}{ Epacridaceae } & & Acroiriche serrulata & 0 & + & + & 0 \\
\hline & & Astroloma humifusum & a & 0 & 0 & 0 \\
\hline & & Epacris impressa & 0 & + & 0 & 0 \\
\hline & $\mathrm{e}, \mathrm{s}$ & Epacris virgala & $\mathbf{a}$ & $\mathrm{a}$ & $\mathrm{a}$ & a \\
\hline & & Styphelia adscendens & & + & + & \\
\hline \multirow[t]{3}{*}{ Fabaceac } & & Bossiaea prostrata & 0 & + & + & \\
\hline & & Hovea heierophylla & + & + & & \\
\hline & & Pultenaea stricta & & & & o \\
\hline Goodeniaceae & & Goodenia lanata & 0 & + & + & + \\
\hline \multirow[t]{2}{*}{ Haloragaceae } & & Gonocarpus tetragynus & 0 & 0 & + & 0 \\
\hline & & Gonocarpus teucrioides & & + & & \\
\hline \multirow[t]{2}{*}{ Lauraceac } & & Cassytha glabella & + & + & & \\
\hline & & Cassytha pubescens & & & & + \\
\hline \multirow[t]{4}{*}{ Mimosaceae } & & Acacia dealbaia & & 0 & & \\
\hline & & Acacia melanoxylon & + & & & \\
\hline & & Acacia mucronaia & & & + & \\
\hline & & Acacia verticillata & & 0 & & \\
\hline \multirow[t]{4}{*}{ Myrtaceae } & & Baeckea ramosissima & & & 0 & 0 \\
\hline & $\mathrm{e}$ & Eucalypius arnygdalina & a & $\mathrm{a}$ & $a$ & a \\
\hline & & Eucalyptus ovata & 0 & 0 & 0 & 0 \\
\hline & & Leptospermum scoparium & & + & & \\
\hline Oleaceae & & Notelaea ligustrina & & + & & \\
\hline Oxalidaceae & & Oxalis corniculata & & & + & \\
\hline Pittosporaceae & & Bursaria spinosa & & & 0 & + \\
\hline Polygalaceae & & Comesperma volubile & 0 & + & + & + \\
\hline \multirow[t]{3}{*}{ Proteaceae } & & Banksia marginala & $\mathrm{a}$ & a & a & a \\
\hline & e & Hakea epiglottis & & & & + \\
\hline & c & Lomatia tinctoria & o & 0 & + & $\mathrm{o}$ \\
\hline \multirow[t]{3}{*}{ Rhamnaceae } & $\mathrm{e}$ & Pomaderis elliptica & & & $\mathrm{a}$ & \\
\hline & es & $\begin{array}{l}\text { Pomaderris pilifera } \\
\text { Spyridium obcordalum }\end{array}$ & $a$ & + & & $\begin{array}{l}+ \\
\mathrm{a}\end{array}$ \\
\hline & $c, 3$ & 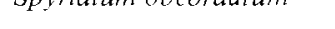 & a & + & 0 & a \\
\hline
\end{tabular}


APPENDIX 1

List of Vascular Species Associated with Tetratheca gunnii Hook. F. Near Beaconsfield.

\begin{tabular}{|c|c|c|c|c|c|c|}
\hline & & & \multicolumn{4}{|c|}{ SITE } \\
\hline & & & 1 & 2 & 3 & 4 \\
\hline Rubiaceae & & Galium australe & & & + & \\
\hline Rutaceae & & $\begin{array}{l}\text { Correa reflexa } \\
\text { Zieria arborescens }\end{array}$ & a & a & a & $\begin{array}{l}\text { a } \\
+\end{array}$ \\
\hline Santalaceae & & Exocarpos cupressiformis & + & + & o & a \\
\hline Stackhousiaceae & & Stackhousia monogyna & & & + & \\
\hline Stylidiaceae & & Stylidium graminifolium & + & & & \\
\hline \multirow{2}{*}{ Tremandraceae } & $\mathrm{e}, \mathrm{s}$ & Tetratheca gunnii & + & + & + & 0 \\
\hline & & Tetratheca pilosa & + & & & 0 \\
\hline \multirow[t]{2}{*}{ Thymelaeaceae } & & Pimelea humilis & 0 & + & & \\
\hline & & Pimelea nivea & & & + & o \\
\hline Violaceae & & Viola hederacea & + & o & + & + \\
\hline \multicolumn{7}{|c|}{ MONOCOTYLEDONS } \\
\hline \multirow[t]{6}{*}{ Cyperaceae } & & Gahnia grandis & + & + & o & a \\
\hline & & Gahnia radula & & o & + & + \\
\hline & & Lepidosperma elatius & & o & & \\
\hline & & Lepidosperma laterale & + & + & o & + \\
\hline & $\mathrm{e}$ & Lepidosperma lineare var.inops & o & & + & + \\
\hline & & Schoenus a pogon & & & + & + \\
\hline \multirow[t]{2}{*}{ Liliaceae } & & Arthropodium milleflorum & & + & & \\
\hline & & Dianella revoluta & & & + & \\
\hline \multirow[t]{5}{*}{ Orchidaceae } & & Acianthus exsertus & & & + & \\
\hline & & Chiloglottis sp. & + & & + & + \\
\hline & & Glossodia major & & & + & \\
\hline & & Pterostylis longifolia & & & + & \\
\hline & & $\begin{array}{l}\text { Pterostylis mutans } \\
\text { Thelymitra } \mathrm{sp} .\end{array}$ & + & $\begin{array}{l}+ \\
+\end{array}$ & + & + \\
\hline \multirow[t]{6}{*}{ Poaceae } & & Deveuxia quadriseta & + & + & & \\
\hline & & Microlaena stipoides & + & o & + & \\
\hline & & Poa sieberana Spreng. & o & o & + & + \\
\hline & e & Stipa aphylla & 0 & o & o & + \\
\hline & & Tetrarrhena distichophylla & + & + & + & \\
\hline & & Themeda australis & + & 0 & & \\
\hline Xanthorrhoeaceae & & Lomandra longifolia & o & o & o & o \\
\hline
\end{tabular}

